\title{
APAKAH PERENCANAAN STRATEGIS DIPENGARUHI OLEH KEPEMIMPINAN \\ (Studi Kasus Perguruan Tinggi Swasta Di Sumatera Utara)
}

\author{
Zulkarnain Siregar \\ Dosen Jurusan Manajemen Fakultas Ekonomi Universitas Negeri Medan
}

\begin{abstract}
Abstrak
Penelitian ini bertujuan untuk mengetahui pengaruh kepemimpinan terhadap perencanaan strategi padad Universitas Swasta di Kota Medan. Populasi dalam penelitian ini adalah Dosen yang ada di Universitas Swasta di Kota Medan dengan Jumlah Sampe sebanyak 250 orang. Penelitian ini diolah dengan menggunakan Partial Least Square (PLS. Hasil penelitian ini terlihat bahwa peranan kepemimpinan akan mempengaruhi perencanaan strategis. Sehingga dalam jangka panjang dan orientasi pengelolaan manajemen pada variabel kepemimpinan akan mampu meningkatkan Kualitas dosen, lulusan dan layanan. Indikator mampu bekerja secara detail dan kemampuan dalam pembelajaran, perbaikan, dan mencari solusi alternatif dalam variabel kepemimpinan akan mampu meningkatkan Kualitas dosen, lulusan dan layanan dalam variabel perencanaan strategis.
\end{abstract}

Kata kunci : Kepemimpinan, Perencanaan Strategis

\section{PENDAHULUAN}

Medan merupakan ibukota propinsi Sumatera Utara merupakan salah satu pintu gerbang terdekat dari negara - negara ASEAN. Dengan masuknya Masyarakat Ekonomi Asean (MEA) Sumatera Utara sangat merasakan dampaknya. Hal ini terlihat dengan banyaknya masuk barang dan sumber daya manusia yang sudah tidak dapat dibendung lagi. Sumber daya manusia merupakan kunci utama dalam menentukan kesuksesan ekonomi.

Sumber daya manusia ditempa dan dibentuk dari lembaga pendidikan dalam hal ini perguruan tinggi. perguruan tinggi memiliki peran sentral dalam mencerdaskan kehidupan bangsa. Peningkatan sumber daya manusia yang dihasilkan oleh perguruan tinggi tergantung dari pengelolaan perguruan tinggi tersebut.
Kompetensi kepemimpinan dalam perguruan tinggi dalam menghadapi tantangan sangat penting dalam mengelola perguruan tinggi (S. Black, 2015). Kepemimpinan perguruan tinggi akan membentuk nilai dan identitas perguruan tinggi tersebut (Joyce, 2012). Kepemimpinan yang baik di perguruan tinggi adalah kepemimipinan yang memiliki kemampuan dalam pembelajaran (S. A. Black, Groombridge, \& Jones, 2011).

Kepemimpinan yang baik memiliki komitmen terhadap departemen yang ada dibawahnya (Bryman, 2007). Komitmen tersebut dapat dituangkan kedalam perencanaan strategik sebagai pengambilan keputusan masa depan (Immordino, Gigliotti, Ruben, \& Tromp, 2012)

Keputusan untuk menghasilkan lulusan yang baik maka diperlukan perencanaan dan 
JURNAL PLANS

Penelitian Ilmu Manajemen \& Bisnis

ISSN: 1978-7057

E-ISSN: 2527-306X

strategi dalam mendesain pembelajaran sesuai dengan dunia nyata (Akomolafe \& Adegun, 2009). Penerapan perencanaan strategi akan menjadikan perguruan tinggi tersebut sukses tidaka hanya visi dan misi yang dipahami oleh departemen tetapi akan mejadikan perguruan tinggi tersebut akan mencapai tujuannya, terkenal dan akan banyak peluang yang dapat diambil (Immordino et al., 2012).

Peran kepemimpinan akan mempengaruhi Perencanaan Strategi (Wilson \& Collier, 2000). Kepemimpinan memiliki peran dalam melakukan perencanaan strategi sehingga memiliki kemampuan dalam menghadapi lingkungan yang tidak pasti (Kiptoo \& Mugambi Mwirigi, 2014). Kesuksesan organisasi dapat dilihat dari perencanaan strategi yang melibatkan peran kepemimpinan dalam melaksanakannya (Hayward, 2008). Berdasarkan hal tersebut diatas maka kerangka konsep penelitian dapat dilihat sebagai berikut:

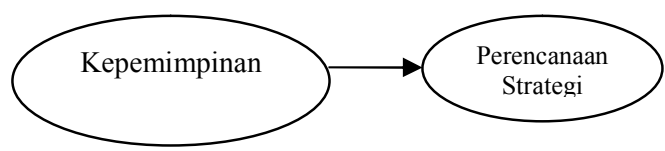

Gambar 1. Kerangka Konsep

\section{METODE PENELITIAN \\ Lokasi Penelitian}

Penelitian ini dilaksanakan pada Universitas Swasta yang ada di Kota Medan dengan kriteria memiliki akreditasi B.

\section{Populasi dan Sampel}

Dalam penelitian ini populasi yang digunakan adalah dosen yang ada di Universitas swasta tersebut. Pengambilan sampel menggunakan metode convinience sampling sebanyak 250 orang.

\section{Variabel Penelitian dan Defenisi}

Operasional

Variabel Penelitian

Adapun yang menjadi variabel dalam penelitian ini adalah sebagai berikut:

1. Variabel bebas (X) : Kepemimpinan

2. Variabel terikat (Y) Perencanaan Strategi

\section{Defenisi Operasional}

Penelitian ini memiliki definisi operasional sebagai berikut :

1. Kepemimpinan (X)

Kepemimpinan adalah kemampuan dalam menjelaskan visi dalam jangka panjang, orientasi pengelolaan manajemen, mampu bekerja secara detail, dan memiliki kemampuan dalam pembelajaran, perbaikan, dan mencari solusi alternatif. (S. A. Black et al., 2011)

Indikator dari Kepemimpinan yang digunakan pada penelitian ini adalah:

a. kemampuan dalam menjelaskan visi dalam jangka panjang

b. orientasi pengelolaan manajemen

c. mampu bekerja secara detail

d. kemampuan dalam pembelajaran, perbaikan, dan mencari solusi alternatif

2. Perencanaan Strategi (Y)

Perencanaan Strategi adalah usaha manajerial dalam menyusun rencana strategis yang kemudian untuk mencapai tujuan tersebut diperlukan kebijakan yang berusaha untuk 
mencapai dan memenuhi strategi tersebut.

Indikator-indikator dari Perencanaan Strategi yang digunakan dalam penelitian ini antara lain:

a. Peningkatan Kualitas Dosen

b. Strategi Peningkatan Kualitas Lulusan

c. Kebijakan mutu layanan

\section{Teknis Analisis Data}

Analisis Regresi Linear Sederhana

Analisis Regresi digunakan untuk mengetahui seberapa besar pengaruh variable $\mathrm{X}$ (Karakteristik Pekerjaan dan Karakteristik Organisasi) terhadap variabel $\mathrm{Y}$ (Kepuasan Kerja).

Dalam penelitian ini analisis regresi yang digunakan adalah analisis regresi linear

Kemudian alat yang digunakan dalam pengolahan data pada penelitian ini adalah Partial Least Square (PLS).

\section{Pengujian Hipotesis}

Uji t

Uji $t$ digunakan untuk menguji secara parsial apakah variabel bebas (X) mempunyai pengaruh signifikan terhadap nilai variabel terikat $(\mathrm{Y})$ dengan Kriteria pengambilan keputusan:

Ho diterima jika $t_{\text {hitung }}<1,96$ pada $\alpha$ $=5 \%$

Ha diterima jika $t_{\text {hitung }}>1,96$ pada $\alpha$ $=5 \%$.

\section{Koefisien Determinasi $\left(\mathbf{R}^{\mathbf{2}}\right)$}

Dari perhitungan $\mathrm{r}$ (korelasi) dapat dilihat hubungan variabel bebas (X) dan variabel terikat (Y) positif atau negatif hubungan tersebut. Determinan digunakan untuk melihat kontribusi variabel bebas $(\mathrm{X})$ terhadap variabel terikat.

\section{HASIL PENELITIAN DAN \\ PEMBAHASAN}

Hasil Penelitian

Berdasarkan hasil perhitungan diperoleh hasil sebagai berikut:

Tabel 1. Hasil Perhitungan Mean, STDEV, T-Values, P-Values

\begin{tabular}{|l|c|c|c|c|c|}
\hline & $\begin{array}{c}\text { Origi } \\
\text { nal } \\
\text { Sam } \\
\text { ple } \\
\text { (O) }\end{array}$ & $\begin{array}{c}\text { Sa } \\
\mathbf{m p l} \\
\mathbf{e} \\
\text { Mea } \\
\mathbf{n} \\
\text { (M) }\end{array}$ & $\begin{array}{c}\text { Stand } \\
\text { ard } \\
\text { Devia } \\
\text { tion } \\
\text { (STD } \\
\text { EV) }\end{array}$ & $\begin{array}{c}\mathbf{t} \\
\text { Stati } \\
\text { stic } \\
\mathbf{s} \\
(\mid \mathbf{O} / \\
\text { STD } \\
\text { EV|) }\end{array}$ & $\begin{array}{c}\text { Palu } \\
\text { es }\end{array}$ \\
\hline $\begin{array}{l}\text { Kepemim } \\
\text { pinan -> } \\
\begin{array}{l}\text { Perencan } \\
\text { aan } \\
\text { Strategis }\end{array}\end{array}$ & 0,751 & $\begin{array}{c}0,75 \\
2\end{array}$ & 0,027 & $\begin{array}{c}27,7 \\
23\end{array}$ & $\begin{array}{c}0,00 \\
0\end{array}$ \\
\hline
\end{tabular}

Dari hasil perhitungan diatas terlihat nilai $\mathrm{T}$ statistics $>$ dari 1,96 artinya hipotesis kepemimpinan berpengaruh terhadap perencanaan strategis. Selanjutnya nilai Average Variance Extracted (AVE) dapat dilihat seperti Tabel 2 di bawah ini.

Tabel 2. Construct Reliability and Validity

\begin{tabular}{|l|r|r|l|l|}
\hline & $\begin{array}{l}\text { Cronba } \\
\text { ch's } \\
\text { Alpha }\end{array}$ & $\begin{array}{l}\text { rho } \\
\text { A }\end{array}$ & $\begin{array}{l}\text { Comp } \\
\text { osite } \\
\text { Reliab } \\
\text { ility }\end{array}$ & $\begin{array}{l}\text { Averag } \\
\text { e } \\
\text { Varianc } \\
\text { e } \\
\text { Extract } \\
\text { ed } \\
\text { (AVE) }\end{array}$ \\
\hline $\begin{array}{l}\text { Kepemimpi } \\
\text { nan }\end{array}$ & 0,876 & $\begin{array}{r}0,87 \\
7\end{array}$ & 0,915 & 0,731 \\
\hline $\begin{array}{l}\text { Perencanaa } \\
\text { n Strategis }\end{array}$ & 0,694 & $\begin{array}{r}0,69 \\
9\end{array}$ & 0,831 & 0,622 \\
\hline
\end{tabular}

Berdasarkan Tabel 2 ini dapat dilihat nilai AVE lebih besar dari 0,5. Kemudian nilai Composite Reliability lebih besar dari 0,7 yang artinya memiliki nilai reliabilitas yang baik. Dan nilai Cronbach's Alpha lebih besar dari 0,6 yang mendukung nilai Composite Reliability artinya reliabilitas pada model ini cukup baik. 


Selanjutnya untuk melihat
apakah model ini terjadi
multikolinearitas atau tidak dapat
dilihat pada Tabel 3 dan Tabel 4 di
bawah ini:
Tabel 3. Inner VIF Value
\begin{tabular}{|l|l|l|}
\hline & $\begin{array}{l}\text { Kepemim } \\
\text { pinan }\end{array}$ & $\begin{array}{l}\text { Perencanaan } \\
\text { Strategis }\end{array}$ \\
\hline Kepemimpinan & & \multicolumn{1}{c|}{$\mathbf{1 , 0 0 0}$} \\
\hline $\begin{array}{l}\text { Perencanaan } \\
\text { Strategis }\end{array}$ & & \multicolumn{1}{|c|}{} \\
\hline
\end{tabular}

Tabel 4. Outer VIF Value

\begin{tabular}{|l|r|}
\hline & VIF \\
\hline X1-1 & $\mathbf{2 , 8 6 5}$ \\
\hline X1-2 & 3,329 \\
\hline X1-3 & $\mathbf{1 , 8 7 7}$ \\
\hline X1-4 & $\mathbf{1 , 9 6 3}$ \\
\hline X2-1 & 1,272 \\
\hline X2-2 & $\mathbf{1 , 3 8 2}$ \\
\hline X2-3 & $\mathbf{1 , 5 4 6}$ \\
\hline
\end{tabular}

Berdasarkan Tabel 3 dan Tabel 4 diatas model penelitian ini tidak memiliki Multikoliniearitas antar variabel karena nilai VIF nya dibawah 5. Kemudian model penelitian ini memiliki nilai $\mathrm{R}^{2}$ seperti Tabel 5 dibawah ini:

Tabel 5. Nilai $\mathbf{R}^{2}$

\begin{tabular}{|l|l|l|}
\hline & $\begin{array}{l}\text { R } \\
\text { Squar } \\
\text { e }\end{array}$ & $\begin{array}{l}\text { R Square } \\
\text { Adjusted }\end{array}$ \\
\hline $\begin{array}{l}\text { Perencanaan } \\
\text { Strategis }\end{array}$ & 0,564 & 0,564 \\
\hline
\end{tabular}

Berdasarkan hasil tersebut diatas bahwa Nilai $\mathrm{R}^{2}$ penelitian ini sebesar 0,564. Sehingga nilai koefisien determinasinya sebesar 56,4\%. Artinya Variabel kepemimpinan mempengaruhi perencanaan strategis sebesar $56,4 \%$. Sisanya dipengaruhi variabel lain lain.

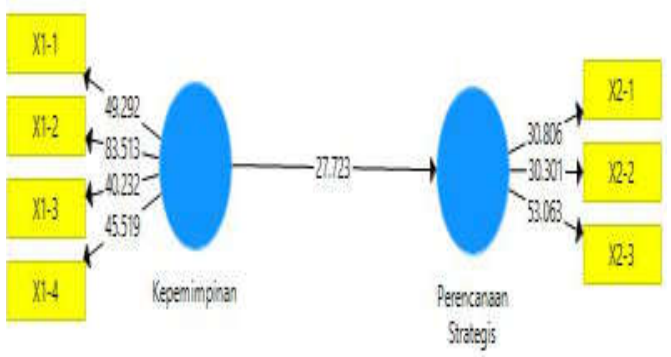

Gambar 2. Hasil Perhitungan Pembahasan Hasil Penelitian Kepemimpinan berpengaruh terhadap perencanaan strategis

Hasil penelitian ini didukung oleh pendapat (Snyman \& Kruger, 2004) yang menyatakan bahwa pernyataan Visi dan Misi harus berhubungan dengan tujuan masa depan perusahaan. Selain itu menurut hasil penelitian yang mereka lakukan bahwa seorang pemimpin harus aktif dan ikut serta dalam melakasnakan strategi yang telah diciptakan tersebut. Sehingga kemampuan Seorang pemimpin dalam menjalankan roda organisasi harus bisa menyusun visi dan misi perusahaan. Dimana perusahaan tersebut harus menurunkan dan mensosialisasikan visi dan misi tersebut kepada bawahannya sehingga tujuan utama perusahaan tersebut tercapai. Untuk menciptakan keberhasilan dalam lingkungan yang kompleks perlu menetapkan kepentingan sehingga hubungan antara kepemimpinan dan perencanaan strategis didasarkan pada peran kepemimpinan dan tanggung jawab untuk membangun dasar tindakan strategis dan menempatkan strategi sebagai perencanaan untuk bekerja (Morgan, 2011). Kemudian (Kiptoo \& Mugambi Mwirigi, 2014) menyatakan bahwa Kepemimpinan dalam sebuah organisasi adalah 
landasan dari sukses dimana kepemimpinan harus mampu menjalan visi, misi dan tujuan dari organisasi untuk mencapai tujuan ditetapkan. Jika kepemimpinan gagal maka perencanaan strategis tidak akan berhasil sehingga, akan mempengaruhi perencanaan strategis organisasi. Ini berarti bahwa keberhasilan rencana strategis ditentukan oleh kepemimpinan organisasi sebagai penegmudi organisasi dalam melaksanakan kegiatan yang berhubungan dengan pelaksanaan. Kepemimpinan adalah melakukan perencanaan yang akhirnya akan mengarah kepada tugas - tugas manajerial tertentu (Fairholm, 2009). Ketergantungan pada dan prioritas nilai-nilai, tujuan, dan identitas adalah hal utama yang mendorong berpikir strategis, sedangkan pencapaian tujuan dan kontrol peristiwa ditindaklanjuti didorong perencanaan strategis.

Kemudian (Rajasekar \& Khoud, 2014) menyatakan bahwa kepemimpinan sebagai faktor yang berpengaruh efektivitas kepemimpinan dalam keberhasilan pelaksanaan strategi datang berdasarkan peran informasi dan sistem kontrol.

\section{PENUTUP}

Dari hasil penelitian pada Universitas swasta yang ada di Kota Medan terlihat bahwa peran kepemimpinan sangat berpengaruh terhadap perencanaan strategis. Kemampuan dalam menjelaskan visi dalam jangka panjang dan orientasi pengelolaan manajemen pada variabel kepemimpinan akan mampu meningkatkan Kualitas dosen, lulusan dan layanan. Selanjutnya indikator mampu bekerja secara detail dan kemampuan dalam pembelajaran, perbaikan, dan mencari solusi alternatif dalam variabel kepemimpinan akan mampu meningkatkan Kualitas dosen, lulusan dan layanan.

\section{DAFTAR PUSTAKA}

Akomolafe, C. O., \& Adegun, O. A. (2009). Strategies of managing higher education for youth labour market in Nigeria. International NGO Journal, 4(10), 456-460.

Black, S. (2015). Qualities of Effective Leadership in Higher Education. Open Journal of Leadership, (June), 54-66. https://doi.org/http://dx.doi.org/ 10.4236/oj1.2015.42006

Black, S. A., Groombridge, J. J., \& Jones, C. G. (2011). Leadership and conservation effectiveness: Finding a better way to lead. Conservation Letters, 4(5), 329-339. https://doi.org/10.1111/j.1755263X.2011.00184.x

Bryman, A. (2007). Effective Leadership in Higher Education. Research and Development Series. https://doi.org/10.1002/chir.209 71

Fairholm, M. R. (2009). Leadership and Organizational Strategy. The Innovation Journal: The Public Sector Innovation Journal, 14(1), 1-16.

Hayward, F. M. (2008). Strategic planning for higher education in developing countries. Planning for Higher Education, 36(3), 521.

Immordino, K. M., Gigliotti, R. A., 
Ruben, B. D., \& Tromp, S.

(2012). Evaluating the Impact of Strategic Planning in Higher Education. Educational Planning, 23(1), 35-47.

Joyce, P. (2012). Sustaining Academic Leadership in Higher Education, 69-81.

Kiptoo, J. K., \& Mugambi Mwirigi,

F. (2014). Factors That

Influence Effective Strategic

Planning Process In

Organizations. IOSR Journal of

Business and Management Ver. II, 16(6), 2319-7668.

Morgan, S. L. L. (2011). Strategic

planning and leadership :

Cuadenos Latinoamericanos de

Administration, v11(12), 9-20.

Rajasekar, J., \& Khoud, A. (2014).

Factors affecting Effective

Strategy Implementation in a

Service Industry: A Study of

Electricity Distribution

Companies in the Sultanate of

Oman. International Journal of

Business and Social Science, 5(9), 169-183.

Snyman, R., \& Kruger, C. J. (2004).

The interdependency between

strategic management and

strategic knowledge

management. Journal of

Knowledge Management, 8(1), 5-19.

https://doi.org/10.1108/1367327

0410523871

Wilson, D. D., \& Collier, D. a.

(2000). An Empirical

Investigation of the Malcolm

Baldrige National Quality

Award Causal Model. Decision

Sciences, 31(2), 361-383.

https://doi.org/10.1111/j.1540-

5915.2000.tb01627.x 